Огляди літератури, оригінальні дослідження, погляд на проблему

удК 616.37-089:616.9-022.7

DOI 10.11603/1811-2471.2016.v0.i4.7068

\title{
ІНФЕКЦІЙНІ ЧИННИКИ У ФОРМУВАННІ ТЕРАПЕВТИЧНОЇ ПАТОЛОГІЇ ПІДШЛУНКОВОЇ
} ЗАЛОЗИ

\author{
○ О. Р. Шайген, Л. С. Бабінець \\ ДВНЗ «Тернопільський державний медичний університет імені І. Я. Горбачевського МОз України»
}

РЕЗЮМЕ. У статті проаналізовано літературні джерела, в яких висвітлено роль інфекції у виникненні панкреатиту. Враховуючи різноманітність чинників формування хронічного панкреатиту, припускається поєднане ушкодження підшлункової залози кількома факторами одночасно.

КЛЮчОВІ СЛОВА: підшлункова залоза, хронічний панкреатит.

Вступ. Проблема хронічного панкреатиту (ХП) $є$ однією із актуальних у сучасній медицині. За останні роки збільшилась увага до інфекційного чинника, який може призвести до розвитку запального процесу в підшлунковій залозі (ПЗ).

Мета дослідження: на основі вивчення літературних джерел оцінити роль інфекції у виникненні панкреатиту.

Основна частина. Хвороби підшлункової залози (ПЗ) i, зокрема, хронічний рецидивний панкреатит (ХРП), доволі поширені в клініці внутрішніх хвороб, однак діагностика і лікування їх все ще складають значні труднощі. В останні роки відзначається зріст даної патології, особливо в осіб працездатного віку, що пов'язують не тільки із збільшенням зловживання алкоголем, порушенням харчування, хронічним стресом і несприятливими екологічними факторами, а й з покращенням діагностики ураження ПЗ [4].

В основі розвитку ХРП лежить ушкодження ацинарних клітин ПЗ різноманітними екзогенними та ендогенними факторами, серед яких найпоширеніші хронічний алкоголізм (від 25 до $80 \%$ ) і хвороби біліарної системи (від 25 до 40 \%). У 5 \% випадків ХРП відносять до "ідіопатичних" захворювань, причину виникнення якого встановити при застосуванні сучасних методів діагностики неможливо [4].

В останні роки все більше уваги приділяється інфекційним чинникам, вплив яких може призвести до розвитку запального процесу в ПЗ [4]. Причинами його виникнення можуть бути епідемічний паротит, вірус гепатиту, ентеровіруси, аденовірус, віруси Коксакі, мікоплазмоз, сальмонельоз, гельмінтоз тощо [5].

За останні 25 років накопичилися експериментальні та клінічні дані, які свідчать про причетність вірусів герпесу, в тому числі цитомегаловірусів, до патогенезу атеросклерозу, який $\epsilon$ одним із чинників виникнення ХП. Вперше цю концепцію висунули у 1973 p. E. Benditt i J. Benditt, які запропонували теорію "доброякісної неоплазії", згідно із якою атеросклеротична бляшка розвивається у результаті клональної експансії єдиної клітини, мутація якої спричинена впливом вірусного чинника [5].

Головними біологічними і патогенетичними особливостями герпесвірусів $\epsilon$ їх пожиттєве персистування в організмі хоча 6 один раз інфікованої ними людини, найсильніша залежність перебігу хронічного інфекційного процесу від стану імунітету вірусоносія і схильність до рецидиву [5]. Рецидивуюча герпесвірусна інфекція щелепнолицевої ділянки у 89 \% випадків поєднується 3 ерозивно-виразковими ураженнями гастродуоденальної зони, у 57 \% - з патологією жовчовивідних шляхів, у $68 \%$ - із захворюваннями кишечника, у $31 \%$ - із захворюванням ПЗ, у $97 \%$ - лОРпатологією, у $62 \%$ - з хворобами сечостатевої системи, у $42 \%$ - із захворюваннями дихальної системи [1].

3 найбільшою ймовірністю розглядається роль цитомегаловірусної інфекції (ЦМВІ) у виникненні ХРП. У роботах останніх років показано, що специфічні цМВІ-антитіла наявні у $90 \%$ дорослого населення. Значно рідше титр антитіл перевищує критичні величини, характерні для латентної ЦМВІ [4].

Принциповими та відмітними особливостями ЦМBI $\epsilon$ найширший спектр клініко-патогенетичних варіантів інфекції і можливість ураження будь-яких органів і систем людини [4].

На сьогодні багато дослідників пов'язують розвиток атеросклерозу з імунозапальним процесом у судинній стінці, який виникає у відповідь на пошкодження ендотелію різними агентами i, зокрема, цитомегаловірусом, з наступною альтерацією матриксу судин ліпідами [4].

Доведено, що ЦМВІ здатна підвищувати атерогенність ліпопротеїдів низької щільності, пригнічувати активність ферментних систем, які здійснюють гідроліз жирів холестерину, а також пригнічувати антикоагулянтні властивості ендотелію [4].

Отже, розвитку і прогресуванню ішемічної хвороби серця і ХРП притаманні подібні патогенетичні механізми, які проходять стадію запалення [4]. 
Огляди літератури, оригінальні дослідження, погляд на проблему

Цитомегаловірус пошкоджує ПЗ з появою симптомів ХП. При розгорнутій клінічній картині герпесвірусних інфекцій (цитомегаловірусної інфекції, вірусу Епштейна-Барр) терапевти встановлюють різноманітні клінічні діагнози, в тому числі гепатиту, панкреатиту [5].

На сьогодні здатність до хронізації інфекції доведена для вірусів гепатиту HBV, HCV, HDV (який існує в організмі тільки при наявності HBV та HGV). Для цих вірусів характерні однакові шляхи поширення (в тому числі через кров та їі продукти) і тривала персистенція в організмі. З'явилися повідомлення про окремі випадки хронізації гепатиту $A$, які свідчать про можливу персистенцію HAV. Одним 3 найважливіших відкриттів останніх років $\epsilon$ встановлення факту реплікації HBV і HCV у тканинах лімфатичного i нелімфатичного походження. Це сприяло розумінню патогенезу багатосистемності ураження, який спостерігається при даних інфекціях, що дозволяє розглядати вірусний гепатит не як хворобу печінки, а як інфекційне захворювання, або системну (генералізовану) інфекцію [5].

Особливе значення має розвиток панкреатиту на тлі вірусної інфекції В і С. Патогенез ураження ПЗ, так само, як і печінки, складається із реплікації вірусів в цих органах, гетерогенності генотипів i мутації геномів вірусів, прямого цитопатичного ефекту (для HCV), імунопатологічних змін у печінці і ПЗ, спільних імунологічних порушень. Так, антигени HBV і ДНК HBV в інтегративній та реплікаційній формах виявляються в ацинарних, протокових, ендокринних клітинах П3, а HBsAg - і в панкреатичному секреті. В 1998 р. низкою дослідників була виявлена PHK HCV в тканинах ПЗ у 3 із 8 померлих внаслідок різних клінічних варіантів HCVінфекції. Імунопатологічні зміни, як при захворюваннях печінки, так і у випадках комбінації цих захворювань 3 панкреатитом, можуть бути представлені двома варіантами: поєднанням реакції ГЗТ з імунокомплексними процесами і патологією переважно імунокомплексного генезу. У першому випадку домінують паренхіматозні, у другому - судинні (васкуліти) зміни, причому особливе значення надається змішаній кріоглобулінемії (особливо при HCV-інфекції). У частини хворих на хронічний гепатит С спостерігається синдром Шегрена ("сухий" синдром: сіалоаденіт+кератокон'юнктивіт+панкреатит із зовнішньосекреторною недостатністю ПЗ). Ушкодження ПЗ при вірусних гепатитах В і С може проявлятись у вигляді цукрового діабету, пов'язаного як із реплікацією вірусів в ендокринних клітинах органа, так і з імунопатологічним процесом. Частіше цукровий діабет розвивається при хронічній HCV-інфекції. У таких паці$\epsilon$ нтів у крові підвищується титр аутоантитіл до інсуліну і розвивається резистентність до нього [2].
Можна виділити наступні особливості перебігу хронічного вірусного панкреатиту В і С:

- наявність маркерів HBV- або HCV-інфекції;

- поєднання з хронічним гепатитом або цирозом печінки;

- відсутність або мінімальна вираженість больового синдрому;

- відсутність чіткої гіперферментемії (цитолізу та ацинарних клітин, гепатоцитів);

- мінімальні, повільнопрогресуючі симптоми зовнішньосекреторної недостатності ПЗ;

- часто ушкодження ПЗ перебігає за типом індуративно-фіброзного ("псевдотуморозного") панкреатиту з позапечінковим холестазом [2].

Оскільки ПЗ $\epsilon$ потужним джерелом синтезу травних ферментів і найчутливішим до пошкодження органом черевної порожнини, то порушення її функції проявляється формуванням зовнішньосекреторної недостатності, а в результаті - синдромами мальдигестії та мальабсорбції. При цьому порушення функціонального стану ПЗ не завжди супроводжується грубими змінами ії структури [7].

Ентеровірус RNA геном - flanked із непереведеною ділянкою (NTR) разом із 5 ' NTR coxackie virus B3 (CVB3) 1-го типу утворює вірус потомства (poliovirus). Отриманий "фантастичний" вірус (CPV/49) копіюється в панкреатоцитах і викликає запалення в тканинах ПЗ. Одне щеплення із введенням CPV/49 експериментальним мишам стимулює захисні anti-CVB3 у нейтралізуючих антитіло титрах, що повністю захищає тварин від панкреатичної хвороби [5].

Зустрічається гострий початок діабету 1-го типу після тяжкої еховірусної інфекції. У відділенні медичної мікробіології університетської лікарні Nijmegen (Нідерланди) вважають, що заразні хвороби, зокрема викликані ентеровірусами, призводять до розвитку цукрового діабету 1-го типу. Розглядались два можливі механізми цього процесу: вірус руйнує ß-клітини шляхом цитолізу або сприяє розвитку аутоімунних явищ. Віруси були ізольованими і культивувались із $\beta$-клітин. Віруси Коксакі В 3-го серотипу активно розмножувались, і все закінчилося швидким зростанням їх кількості і масивною смертю $\beta$-клітин. Еховіруси не розмножувались при культивуванні В $\beta$-клітинах, не було виявлено антитіл до компонентів останніх і прямої цитолітичної дії на ß-клітини. Автори роблять висновок, що ентеровіруси викликають цукровий діабет за допомогою інших механізмів [5].

Для інсулінозалежного діабету характерна сезонність захворюваності: підвищення відбувається в осінні і зимові місяці, із піком у жовтні та в січні, причому мінімум нових випадків діабету 
Огляди літератури, оригінальні дослідження, погляд на проблему

відмічають у червні та липні. Максимум захворюваності на цукровий діабет у дітей відмічається у віці 5 та 11 років, що, ймовірно, пов'язано з можливістю впливу на його розвиток різних вірусних захворювань. На сьогодні вважають, що у тварин виникненню цукрового діабету сприяє інфікування вірусами енцефаломіокардиту, Коксакі, менінговірусом 2-го типу, реовірусом 1-го та 2-го типів, вірусом краснухи. У людини в патогенезі інсулінозалежного діабету певна роль відводиться вірусам Коксакі В-3 і В-4, реовірусу 3-го типу, вірусу паротиту, цитомегаловірусу і вродженій краснусі. Інші віруси (вірус гепатиту та ін.) набагато менше беруть участь у виникненні цукрового діабету, якщо взагалі беруть участь. Роль вірусної інфекції у походженні діабету, ймовірно, зводиться до того, що віруси первинно ініціюють пошкодження В-клітин в осіб із генетичною схильністю до такого пошкодження. Як правило, від моменту появи вірусного захворювання до початку цукрового діабету проходить певний час [5].

Панкреатит нерідко розвивається при СНІДі, проте через його латентний перебіг лікарі не звертають увагу на стан ПЗ. При обстеженні 86 ВІЛ-інфікованих, які не мали клінічних проявів панкреатиту, у 52 із них (60\%) виявили гіперамілаземію або (i) гіперліпаземію. У 12 обстежених (14\%) отримані показники перевищували норму більше, ніж у 2 рази [2].

Розвиток при СНІДі склерозуючого холангіту також створює передумови до залучення у патологічний процес ПЗ у рамках мультифокального фіброзу, через стенозування фатерового сосочка. Крім цього, в якості потенційної причини склерозуючого холангіту при СНІДі виступають криптоспоридії і цитомегаловірус. Останній, як вже вказувалось вище, здатний викликати панкреатит [2].

Передбачається можливість розвитку холестатичних захворювань печінки, патології ПЗ внаслідок впливу Helicobacter pylori i Helicobacter bilis. Ведуться дослідження з вивчення ролі Helicobacter pylori (виділений із печінки людини) і Helicobacter bilis (виділений із жовчного міхура людини) у виникненні захворювань печінки і ПЗ. Один або обидва види мікроорганізму виявляються у тканинах печінки (у жовчі) в 75 \% випадків первинного склерозуючого холангіту, в 92 \% випадків первинного біліарного цирозу і в 75 \% випадків гепатоцелюлярної карциноми та холангіокарциноми. Доведена обтяжуюча дія інфекції Helicobacter pylori на перебіг хронічного панкреатиту. Проте ці відомості $\epsilon$ попередніми [2].
Ймовірність розвитку інвазивних мікозів визначається основним захворюванням і рядом інших факторів, зокрема антибактеріальною терапією двома препаратами і більше, колонізацією грибами слизових оболонок, шкіри. Достовірно частіше інвазивний кандидоз розвивається при панкреатиті [5].

Нерідко при автоімунному і неімунному панкреатитах (відповідно в 20,6 \% і 14,3 \% випадків) хронічному панкреатиту передує опісторхоз, який $\epsilon$ причиною ураження ПЗ. Клінічні варіанти перебігу ранньої стадії захворювання різноманітні - від стертих форм до генералізованих алергічних реакцій із множинними ураженнями. Стерта форма обмежується субфебрилітетом, незначною еозинофілією при нормальному вмісті лейкоцитів. Хронічна стадія пов'язана із життєдіяльністю паразитів у жовчних протоках печінки і Пз. Спостерігається хронічне проліферативне запалення у протоковій системі ПЗ, що супроводжується фіброзом різного ступеня із дифузними змінами і ретенційними кістами в ПЗ. Наявні в даний час імунологічні методи діагностики опісторхозу і клонорхозу недостатньо специфічні і чутливі, і їх інколи доцільно використовувати лише як додадкові до паразитологічних методів. Паразитологічна діагностика, заснована на дослідженні та виявленні яєць гельмінтів у фекаліях і (або) дуоденальному вмісті, в даний час $\epsilon$ єдиним засобом підтвердження діагнозу [5].

Аскаридоз може бути причиною розвитку хронічного панкреатиту при кальцифікації аскарид у вірсунговій протоці [5].

Зміни, характерні для хронічного панкреатиту, трапляються при туберкульозі кишечника і паразитарних його захворюваннях [5].

Описаний при лямбліозі хронічний панкреатит відрізняється більш доброякісним, ніж при його класичній формі, перебігом: доказом лямбліозної етіології захворювання вважають виявлення вказаних збудників у протоках залози та ефект від протипаразитарного лікування. Механізм мальабсорбції при лямбліозі пояснюється зниженням всмоктувальної функції кишечника, а також зміною ферментативної активності тонкої кишки та ПЗ [6].

Висновки. Враховуючи різноманітність чинників формування ХП, серед яких найпоширенішими $\epsilon$ хронічний алкоголізм і хвороби біліарної системи, можна припустити поєднане ушкодження ПЗ кількома факторами одночасно. 
Огляди літератури, оригінальні дослідження, погляд на проблему

\section{ЛІТЕРАТУРА}

1. Бекетова Г. Лікування рецидивуючих герметичних уражень верхніх відділів травного каналу у дітей / Г. Бекетова, Н. Савичук, Н. Алєксєєнко // Ліки України. - 2000. - № 9 - С. 55-57.

2. Губергриц Н. Б. Сочетанные заболевания печени и поджелудочной железы: этиопатогенетические варианты и принципы лечения / Н. Б. Губергриц, Г. М. Лукашевич // Сучасна гастроентерологія. - 2002. № 2 (8). - С. 33-37.

3. Пасиешвили Л. М. Биологическая сущность апоптоза при хроническом цитомегаловирусном панкреатите / Л. М. Пасиешвили, А. А. Заздравнов // Сучасна гастроентерологія. - 2004. - №1 - С. 46-48.

4. Пасиешвили Л. М. Роль вирусной инфекции в поражении поджелудочной железы у больных ишемической болезнью сердца / Л. М. Пасиешвили, А. А. Заздравнов // Врачебная практика. - 2001. - № 4. - C. 43-45.

5. Инфекции и их место среди других причин возникновения панкреатита / Ю. И. Решетилов, А. И. Токаренко, С. Н. Дмитриева // Сучасна гастроентерологія. - 2002. - № 2 (8). - С. 24-29.

6. Тумольская Н. П. Роль лямблий в патологии человека / Н. П. Тумольская // Врач. - 2000. - № 8 С. 23-25.

7. Чернега Н. В. Внешнесекреторная недостаточность поджелудочной железы у детей с хроническим вирусным гепатитом С / Н. В. Чернега, М. Ф. Денисова // Сучасна гастроентерологія. - 2014. - № 1 (75). - C. 29-33.

\title{
INFECTIOUS FACTORS IN THE FORMATION OF THERAPEUTIC PATHOLOGY OF THE PANCREAS
}

\author{
@O. R. Shayhen, L. S. Babinets \\ I. Horbachevsky Ternopil State Medical University
}

SUMMARY. The article analyzes the literature on the role of infection in causing pancreatitis; gives the variety of factors in the formation of chronic pancreatitis, accompanied by assumed damage of pancreatic several factors simultaneously.

KEY WORDS: pancreas, chronic pancreatitis. 